\title{
ANALISIS SISTEM PENGENDALIAN INTERN PENJUALAN KREDIT UNTUK MEMAKSIMALKAN TARGET PENCAIRAN PIUTANG PADA PT BINTANG MULIA JAYA
}

\author{
Kemas Welly Angga Permana \\ Fakultas Ekonomi, Universitas Sjakhyakirti Palembang \\ Email: kemaswelly@unisti.ac.id
}

\begin{abstract}
ABSTRAK
Penelitian ini adalah untuk mengetahui kinerja sistem pengendalian intern penjualan kredit untuk memaksimalkan target pencairan piutang pada PT.Bintang Mulia Jaya apakah sudah sesuai standar atau belum, data sekunder diperlukan sebagai dasar analisis, sedangkan teknik pengumpulan datanya adalah wawancara dan dokumentasi. Metode analisis yang digunakan adalah metode kualitatif komparatif.

Penelitian ini termasuk jenis penelitian deskritif, dimana analisis yang telah dilakukan menyatakan bahwa PT. Bintang Mulia Jaya belum menerapkan sistem pengendalian intern penjualan kredit secara memadai sesuai dengan teori yang ada pada sistem pengendalian intern, ada beberapa fungsi yang terkait dalam penjualan kredit yang tidak kompeten dan tindakan yang diberikan pimpinan kepada fungsi - fungsi yang terkait pada permasalahan yang timbul diperusahaan berupa teguran kepada masing masing fungsi.

Hasil penelitian agar dapat mencapai tujuan yang diharapkan maka penulis menyarankan sebaiknya melakukan perbaikan penerapan sistem pengendalian intern yang ada pada PT. Bintang Mulia Jaya sesuai dengan teori yang ada pada unsur-unsur sistem pengendalian intern.Lebih memperhatikan setiap transaksi yang berhubungan dengan penjualan kredit.
\end{abstract}

Kata Kunci: Sistem, Pengendalian Intern, Penjualan Kredit.

\section{PENDAHULUAN}

\section{LATAR BELAKANG}

Tujuan utama suatu perusahaan adalah mencari laba yang maksimal.Bagi setiap perusahaan, baik itu perusahaan jasa, dagang maupun perusahaan manufaktur, laba yang maksimal dapat diperoleh dari peningkatan volume penjualan. Karena semakin tingginya volume penjualan maka semakin besar pula laba yang akan didapat. Berbagai cara akan dilakukan pihak manajemen untuk meningkatkan volume penjualan, mulai dari pemberian potongan (diskon) baik untuk penjualan cash atau kredit, variasi produk dan pemberian hadiah atau 
souvenir. Kegiatan operasional yang dilakukan oleh PT.Bintang Mulia Jaya adalah melakukan penjualan kendaraan bermotor baik penjualan tunai maupun penjualan secara kredit, penjualan spareparts dan jasa service bengkel khusus Merk Honda. Aktivitas pokok di PT. Bintang Mulia Jaya adalah penjualan sepeda motor secara tunai ataupun kredit. Untuk penjualan tunai perusahaan tidak menghadapi suatu masalah yang cukup berarti karena begitu motor dijual maka kas akan langsung diperoleh. Namun berbeda dengan penjualan kredit, perusahaan tidak langsung memperoleh kas begitu barang dijual, namun perlu mengirimkan tagihan terlebih dahulu ke pihak leasing. Dalam penjualan kredit ada 3 pihak yang terlibat yaitu penjual, pembeli dan leasing.

PT. Bintang Mulia Jaya melakukan penagihan kepada pihak leasing yang dilakukan oleh bagian penagihan setelah bagian gudang memberikan surat jalan kembali atau bukti serah terima kendaraan (BSTK) yang dilampiri purchase order dari leasing. Penagihan piutang ke Leasing dilakukan berdasarkan purchase order yang dikeluarkan langsung oleh leasing setelah credit marketing officer (CMO) atau bagian survey dari leasing melakukan survey kepada konsumen yang telah memenuhi syarat-syarat pemberian kredit. Tetapi perusahaan terkadang mengalami kendala dalam hal penagihan dan pencairan unit dari leasing dikarenakan tidak terbitnya purchase order (PO) meskipun motor sudahdiserahkan kepada konsumen. Hal ini menyebabkan terhambatnya penagihan piutang kepada leasing dan terlambatnya piutang cair yang mengakibatkan tidak maksimalnya target pencairan piutang setiap bulannya yang ditargetkan mencapai 90\% dari total penjualan kredit. Berikut ini daftar total jumlah penjualan kredit dan unit yang cair di PT. Bintang Mulia Jaya.

Tabel 1

Jumlah Penjualan dan Unit cair

PT. Bintang Mulia Jaya

Periode Oktober s/d Desember 2019

\begin{tabular}{|c|c|c|c|c|c|c|c|}
\hline \multirow[b]{2}{*}{ Bulan } & \multirow{2}{*}{$\begin{array}{c}\text { Total } \\
\text { Penjualan } \\
\text { Kredit }\end{array}$} & \multirow{2}{*}{$\begin{array}{c}\text { Target Maksimal } \\
\text { Unit Cair }\end{array}$} & \multirow[b]{2}{*}{ Persentase } & \multicolumn{4}{|c|}{ Realisasi Pencairan Piutang } \\
\hline & & & & $\begin{array}{c}\text { Kurang Dari } \\
1 \text { Bulan }\end{array}$ & Persentase & $\begin{array}{l}\text { Lebih } \\
\text { Dari } 1 \\
\text { Bulan } \\
\end{array}$ & Persentase \\
\hline Oktober & 251 Unit & 226 Unit & $90 \%$ & 218 Unit & $86,8 \%$ & 33 Unit & $13,14 \%$ \\
\hline November & 233 Unit & 210 Unit & $90,1 \%$ & 205 Unit & $87,9 \%$ & 28 Unit & $12,01 \%$ \\
\hline Desember & 283 Unit & 255 Unit & $90,1 \%$ & 246 Unit & $86,9 \%$ & 37 Unit & $13,07 \%$ \\
\hline
\end{tabular}

Sumber : PT. Bintang Mulia Jaya, 2020 
Pada tabel 1 dapat dilihat jumlah unit yang cair kurang dari 1 bulan belum mencapai $90 \%$ dari total penjualan kredit. Padahal perusahaan menargetkan jumlah pencairan unit setiap bulannya harus mencapai $90 \%$ dari total penjualan kredit. Selain berdampak pada tidak tercapainya target jumlah pencairan unit setiap bulannya masalah ini juga berdampak pada cash flow perusahaan yang mengakibatkan kerugian pada perusahaan. Berikut daftar jumlah piutang yang seharusnya cair dan jumlah piutang yang terealisasi kurang dari 1 bulan dan lebih dari 1 bulan.

Tabel 2

Daftar Jumlah Piutang

PT. Bintang Mulia Jaya

Periode Oktober s/d Desember 2019

\begin{tabular}{|c|c|c|c|c|c|}
\hline \multirow[b]{2}{*}{ Bulan } & \multirow{2}{*}{$\begin{array}{l}\text { Jumlah Piutang } \\
\text { yang seharusnya } \\
\text { cair }(\mathrm{Rp})\end{array}$} & \multicolumn{4}{|c|}{ Realisasi piutang cair } \\
\hline & & $\begin{array}{c}\text { Piutang cair } \\
\text { Kurang dari } 1 \\
\text { bulan (Rp) }\end{array}$ & Persentase & $\begin{array}{l}\text { Piutang cair } \\
\text { lebih dari } 1 \\
\text { bulan }(\mathrm{Rp})\end{array}$ & Persentase \\
\hline Oktober & 2.853 .765 .000 & 2.474 .320 .000 & $86,7 \%$ & 379.445 .000 & $13,3 \%$ \\
\hline November & 2.729 .932 .963 & 2.410 .240 .000 & $88,3 \%$ & 319.692 .963 & $11,7 \%$ \\
\hline Desember & 3.244 .635 .000 & 2.849 .350 .000 & $87,8 \%$ & 395.285 .000 & $12,2 \%$ \\
\hline
\end{tabular}

Sumber : PT. Bintang Mulia Jaya Palembang, 2020

Pada tabel 2 dapat dilihat jumlah selisih piutang yang seharusnya cair sesuai penjualan kredit setiap bulan dengan jumlah piutang yang cair kurang dari 1 bulan masih cukup besar. Hal ini dapat mengakibatkan perusahaan mengalami gangguan akibat cash flow yang tidak sesuai dengan piutang yang seharusnya cair. Berdasarkan informasi dari bagian piutang jumlah pencairan unit pada PT.Bintang Mulia Jaya yang belum maksimal setiap bulannya disebabkan oleh keterlambatan purchase order (PO) karena tidak dilakukannya proses penjualan kredit sesuai prosedur yang ditetapkan atau sesuai standar operasional perusahaan (SOP) dalam penjualan kredit dan masih kurangnya kesadaran dari bagian penjualan serta bagian gudang untuk melakukan proses penjualan kredit sesuai aturan standar operasional perusahaan (SOP). Dimana bagian penjualan sering lalai melampirkan purchase order dari leasing pada saat memberikan surat pesanan kendaraan ke bagian gudang. Kemudian bagian gudang yang tetap mengirimkan pesanan 
kendaraan bermotor kepada konsumen meskipun tidak adanya purchase order yang sah dari leasing melainkan hanya konfirmasi via telepon dengan bagian survey kredit pihak leasing, sehingga berdampak terhambatnya pada proses penagihan piutang ke leasing dan tidak maksimalnya target pencairan piutang. Oleh karena itu sangat dibutuhkan sistem pengendalian intern pada PT. Bintang Mulia Jaya untuk bagian-bagian yang terlibat dalam penjualan kredit.

\section{Perumusan Masalah}

Berdasarkan latar belakang dirumuskan permasalahan:“" Bagaimanakah sistem pengendalian intern dalam penjualan kredit untuk memaksimalkan target pencairan piutang yang diterapkan pada PT.Bintang Mulia Jaya, lalu untuk bagian-bagian dan petugas yang terkait dalam penjualan kredit apakah sudah kompeten?"“

\section{KAJIAN PUSTAKA}

\section{Sistem Pengendalian Intern}

Menurut AICPA (American Institute of Certified Public Accountants) seperti diterjemahkan oleh Zaki Baridwan, (2002:13) mendefinisikan pengendalian intern meliputi struktur organisasi dan semua cara-cara serta alat yang dikoordinasikan dan digunakan didalam perusahaan dengan tujuan untuk menjaga keamanan harta milik perusahaan memeriksa ketelitian dan kebenaran data akuntansi, memajukan efisiensi didalam usaha, dan membantu mendorong dipatuhinya kebijakankebijakan manajemen yang telah ditetapkan lebih dulu.

\section{Komponen Pengendalian Intern}

Menurut Committee of Sponsoring Organization of The Treadway Commission (COSO) William C Boynton, Raymond N. Johnson dan Walter G.Kell (2006:373) mendefinisikan struktur pengendalian intern terdiri dari lima kategori dasar kebjikan dan prosedur yang dirancang dan digunakan oleh manajemen untuk memberikan keyakinan memadai bahwa tujuan pengendalian dapat dipenuhi. 


\section{Unsur-Unsur Sistem Pengendalian Intern}

Unsur pengendalian intern adalah penting bahwa sistem mempunyai beberapa unsur atau sifat-sifat tertentu, yang meningkatkan kemungkinan dapat dipercayainya data-data akuntansi serta tindakan pengamanan terhadap aktiva dan catatan perusahaan. Menurut Mulyadi (2001:164) unsur pokok sistem pengendalian intern adalah sebagai berikut :

1) Struktur organisasi yang memisahkan tanggung jawab fungsional secara tegas.

2) Pencatatan yang memberikan perlindungan yang cukup terhadap kekayaan, hutang, sistem wewenang dan prosedur pendapatan dan biaya.

3) Praktek yang sehat dalam melaksanakan tugas dan fungsi setiap unit organisasi.

4) Karyawan yang mutunya sesusai dengan tanggung jawabnya.

\section{Keterbatasan Pengendalian Intern}

Keterbatasan bawaan yang melekat pada pegendalian intern yang dikemukakan oleh Mulyadi (2001:183) adalah sebagai berikut :

1) Kesalahan dalam pertimbangan

Manajemen seringkali salah dalam mempertimbangkan keputusan bisnis yang diambil dan tugas rutin karena tidak memadai informasi dan tekanan lain.

2) Kolusi

Kolusi merupakan tindakan bersama beberapa individu untuk tujuan kejahatan dan dapat mengakibatkan kebobolan pengendalian intern yang dibangun untuk melindungi kekayaan perusahaan dan tidak terungkap ketidakberesan oleh sistem pengendalian intern yang sudah dirancang.

3) Biaya lawan manfaat

Biaya yang diperlukan untuk mengoperasikan sistem pengendalian intern tidak boleh melebihi manfaat yang akan diharapkan dari pengendalian intern tersebut, karena pengukuran secara tepat baik biaya maupun manfaat biasanya tidak mungkin dilakukan, manajemen harus memperkirakan dan mempertimbangkan dalam mengevaluasi biaya dan manfaat suatu pengendalian intern.

4) Gangguan 
Gangguan dalam pengendalian yang telah ditetapkan dapat terjadi karena kelalaian, tidak adanya perhatian atau kelelahan.Perubahan yang bersifat sementara atau permanen dalam proposal atau dalam sistem dan prosedur juga dapat mengakibatkan gangguan.

5) Pengabaian oleh manajemen

Manajemen dapat mengakibatkan kebijakan atau prosedur yang telah ditetapkan untuk tujuan yang tidak sah, seperti keuntungan pribadi manajer, penyajian kondisi keuangan yang berlebihan atau kepatuhan semua.

Beberapa saran untuk mencegah terjadinya kecurangan dari Sukrisno Agoes (2004:229)

1) Tingkatan pengendalian intern yang terdapat pada perusahaan.

2) Lakukan seleksi pegawai secara ketat gunakan psikologi dan hindari katebelece dalam penerimaan pegawai.

3) Tingkat keandalan intern audit department, antar lain memberikan balasjasa yang menarik, memberikan perhatian yang cukup besar terhadap laporan meraka dan mengharuskan internal melaksanakan continuing professional education.

4) Berikan imbalan yang memadai untuk para pegawai.

5) Lakukan rotasi jabatan dan wajibkan para pegawai untuk mempergunakan cuti mereka.

6) Lakukan pembinaan rohani.

7) Berikan sanksi yang tegas kepada mereka yang melakukan kecurangan dan berikan penghargaan kepada mereka yang berprestasi.

8) Tumbuhkan iklim keterbukaan dalam perusahaan.

9) Manajemen harus memberikan contoh bertindak jujur, adil, dan bersih.

10) Buat kebijakan tertulis mengenai fair deadling.

\section{Pengawasan Tambahan}

Untuk menjamin pengawasan intern dengan baik selain terpenuhinya keempat unsur di atas, diperlukan beberapa pengawasan tambahan yang terdiri :

a) Laporan

Unsur laporan juga hal yang penting dalam pelaksanaan pengawasan intern yang baik.Laporan ini diserahkan kepada atasan dengan maksud agar atasan 
dapat mengetahui hasil kegiatan perusahaan. Agar tercapainya pengawasan intern yang memuaskan, sangat diperlukan ketelitian baik dalam penyelenggaraan maupun dalam penentuan apa yang harus dilaporkan maka harus diperhatikan faktor-faktor yang dibutuhkan dalam menyusun laporan, yaitu :

(1) Tepat waktunya, laporan akan hilang nilainya apabila laporan tidak dilaporkan pada waktunya atau terlambat melaporkannya.

(2) Ketelitian, dalam menyusun laporan sangat diperlukan.,karena kesalahan dalam membuat laporan akan membuat kerugian dan tidak berguna lagi bagi perusahaan.

(3) Berguna, kebanyakan laporan dimaksudkan untuk memperlihatkan hasil salah satu fase dalam proses yang dipimpin oleh seorang pegawai. Oleh karena itu agar laporan tersebut dapat dimanfaatkan dengan baik, maka laporan harus dipisahkan jawabnya yaitu segala sesuatu kegiatan transaksi atau kejadian yang ada.

(4) Jelas, laporan-laporan harus memberikan gambaran yang lengkap dan jelas tentang apa-apa yang telah berlangsung. Laporan yang dibuat tentunya setelah berlangsungnya pekerjaan maka laporan harus tepat pada waktunya, teliti, lengkap dan tidak memihak.

b) Standar atau budget

Standar atau budget merupakan alat untuk mengukur realisasi.Dengan adanya standar atau budget maka laporan-laporan itu bisa disusun dengan membandingkan antara realisasi dengan standar atau budgetnya, sehingga dapat diketahui penyimpangan-penyimpangan yang terjadi.

c) Staf audit intern

Staf audit intern merupakan bagian atau pegawai dalam perusahaan yang tugasnya melakukan pemeriksaan terhadap pelaksanaan prosedur-prosedur yang telah ditetapkan. Pemeriksaan ini dapat dipergunakan untuk mengetahui apakah pelaksanana kerja itu sesuai atau menyimpang dari yang sudah ditetapkan.Prosedur-prosedur yang telah disusun dengan tujuan untuk 
mengadakan suatu sistem pengendalian intern, maka dapat mengetahui apakah ketetapan yang sudah ada tersebut dipatuhi atau tidak.

\section{METODOLOGI PENELITIAN}

\section{Desain Penelitian}

Desain penelitian yang dilakukan dalam penelitian ini adalah dengan penelitian deskriptif yang bertujuan untuk mengungkap fakta dalam hubungan sebab akibat.Tujuan penelitian ini untuk menjawab bagaimanakah sistem pengendalian intern pada PT. Bintang Mulia Jaya.

\section{Lokasi Penelitian}

Lokasi penelitian dilakukan melalui PT. Bintang Mulia Jaya di Jl.Alamsyah Ratu Prawira Negara (Samping Perumahan Polygon) Kel.Bukit lama Kec.llir barat I.

\section{Metode Pengumpulan dan Analisa Data}

Teknik pengumpulan data yang digunakan dalam penelitian ini adalah wawancara langsung dengan bagian penagihan piutang, bagian penjualan dan bagian gudang dan mengunakan teknik dokumentasi yakni meminta data yang berhubungan dengan sistem pengendalian intern (SPI) penjualan kredit.

\section{Analisis Data}

Sugiyono (2009: 13-14) analisis data dalam penelitian dapat dikelompokan menjadi dua yaitu:

a. Analisis Kualitatif adalah suatu metode analisis dengan mengunakan data yang berbentuk kata, kalimat, skema dan gambar.

b. Analisis Kuantitatif adalah suatu metode analisis dengan mengunakan data berbentuk angka atau data kualitatif yang diangkakan. Pada penelitian kuantitatif dibedakan pula antara metode penelitian eksperimen dan noneksperimen.Salah satu penelitian yang terdapat dalam metode noneksperimen yaitu penelitian komparatif.Penelitian komparatif adalah jenis penelitian yang digunakan untuk membandingkan antara dua kelompok atau lebih dari suatu variabel tertentu. 
Analisis data yang akan digunakan dalam penelitian ini adalah analisis kualitatif komparatif yang menggambarkan objek penelitian pada saat ini berdasarkan fakta-fakta yang ada tentang sistem pengendalian intern (SPI) penjualan kredit dan pelaksanaan penjualan kredit yang dilakukan.

\section{Teknik analisis}

Teknik analisis yang digunakan dalam penelitian ini yaitu teknik analisis kualitatif komparatif dengan cara membandingkan sistem pengendalian intern (SPI) penjualan kredit dengan teori yang ada dan membandingkan standar operasional perusahaan (SOP) penjualan kredit dengan pelaksanaan penjualan kredit yang terjadi pada perusahaan.Pemisahan fungsi-fungsi operasi dan penyimpangan dari fungsi akuntansi.Serta suatu fungsi tidak diberi tanggung jawab penuh untuk melaksanakan semua tahap transaksi.Transaksi hanya terjadi atas dasar otorisasi dari pejabat yang memiliki wewenang, prosedur pencatatan.Seleksi calon karyawan, pengembangan karyawan, pelaporan, audit intern, integritas dan nilai-nilai etika, serta komitmenterhadap kompetensi.

\section{HASIL DAN PEMBAHASAN}

\section{Hasil Penelitian}

Hasil penelitian menunjukan bahwa pada PT. Bintang Mulia Jaya sistem pengendalian intern penjualan kredit dan target pencairan piutang belum diterapkan secara memadai dikarenakan beberapa dari unsur-unsur sistem pengendalian intern penjualan kredit belum dilakukan dan diterapkan secara maksimal, serta ada juga beberapa fungsi atau bagian yang terkait dalam penjualan kredit yang tidak kompeten dalam bidangnya dan tidak adanya komitmen atau tindakan tegas dari para pimpinan terhadap kelemahan yang terjadi di perusahaan.

Berdasarkan kondisi tersebut, maka sebaiknya PT. Bintang Mulia Jaya harus melakukan perubahan dan perbaikan pada sistem pengendalian intern penjualan kredit yang ada pada perusahaan. Sistem pengendalian intern penjualan kredit yang terdiri dari struktur organisasi penjualan kredit, standar operasional penjualan kredit, praktek yang sehat, sumber daya manusia yang kompeten, pengawasan tambahan dan lingkungan pengendalian dan sistem pengendalian 
intern penjualan kredit yang harus diperbaiki dan diubah adalah pada unsur standar operasional penjualan kredit, praktek yang sehat, sumber daya manusia yang kompeten, pengawasan tambahan dan lingkungan pengendalian.

\section{Struktur Organisasi (STO) penjualan kredit}

Pada PT. Bintang Mulia jaya struktur organisasi penjualan kredit sudah dibentuk secara maksimal. Hal ini bisa dilihat di gambar alur transaksi penjualan kredit dibawah ini:

\section{Gambar 1}

\section{Alur transaksi penjualan kredit}

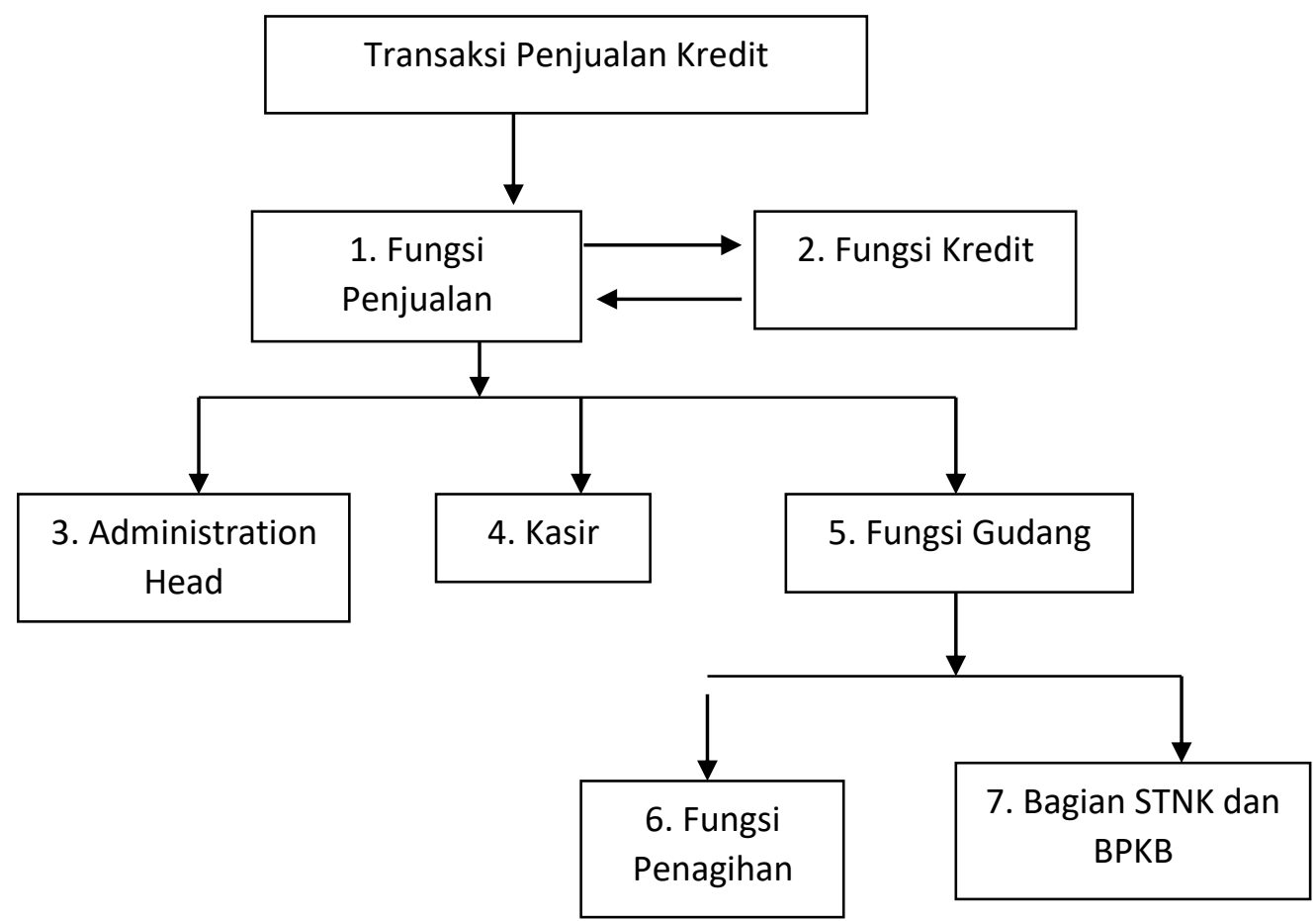

Pada PT. Bintang Mulia jaya struktur organisasi penjualan kredit dinilai dari:

a. Pemisahan fungsi - fungsi yang terkait dalam penjualan kredit.

Berdasarkan hasil penelitian, diketahui bahwa PT. Bintang Mulia Jaya sudah melakukan pemisahan fungsi-fungsi yang terkait dalam penjualan kredit yaitu antara fungsi penjualan (bagian marketing), fungsi kredit, fungsi gudang(bagian gudang), fungsi penagihan dan fungsi akuntansi (bagian kasir) dimana hal ini telah sesuai dengan teori sistem pengendalian intern penjualan 
kredit yang ada, berikut contoh pemisahan fungsi yang terkait dalam sistem pengendalian penjualan kredit yang ada pada PT. Bintang Mulia jaya :

1) Fungsi penjualan yang terpisah dengan fungsi kredit, dimana fungsi penjualan merupakan marketing atau salesman dari intern perusahaan yang mempunyai tugas mencari konsumen dan menjual barang. Sedangkan fungsi kredit merupakan pihak ekstern dari leasing yang berwenang menolak ataupun menerima pemberian kredit kepada konsumen.

2) Fungsi penagihan yang terpisah dengan fungsi gudang dan fungsi penjualan, dimana dalam penjualan kredit fungsi penagihan mencatat piutang yang harus ditagih kepada pihak leasing harus dipisah dengan fungsi penjualan yang melakukan transaksi penjualan kredit serta fungsi gudang yang mengentry data penjualan dari fungsi penjualan.

b. Suatu fungsi tidak diberikan tanggung jawab penuh untuk melaksanakan semua tahap transaksi penjualan kredit.

Berdasarkan hasil penelitian, diketahui bahwa pada PT. Bintang Mulia Jaya setiap melakukan transaksi melibatkan lebih dari satu karyawan atau lebih dari satu fungsi. Dikarenakan, pada dasarnya transaksi yang terjadi saling berhubungan antara fungsi yang satu dengan yang lain sehingga memudahkanuntuk mengecek apabila ada kesalahan. Hasil penelitian ini juga dapat dilihat dari gambar IV.1 yang menunjukan keterkaitan masing masing fungsi dalam transaksi penjualan kredit.

\section{Standar operasional perusahaan (SOP) penjualan kredit}

a. Transaksi hanya terjadi atas dasar otorisasi pejabat atau fungsi yang memiliki wewenang.

Berdasarkan hasil penelitian, diketahui bahwa sistem otorisasi Pada PT. Bintang Mulia Jaya tidak dilakukan secara baik, ada beberapa transaksi penjualan kredit yang tidak mendapatkan otorisasi dari pejabat atau fungsi yang berwenang, transaksi tersebut yaitu terjadi pada penjualan kredit dimana surat pesanan kendaraan yang tidak ada lampiran purchase order dan otorisasi dari fungsi kredit tetapi oleh fungsi gudang diinput menjadi penjualan dan unit kendaraan dikirim ke konsumen sehingga mengakibatkan permasalahan yang 
menganggu operasional perusahaan. Sebaiknya sistem otorisasi penjualan kredit yang seharusnya dilakukan PT. Bintang Mulia Jaya sesuai dengan unsur sistem pengendalian intern yang ada yaitu sebagai berikut:

1) Surat pesanan kendaraan (SPK) yang akan di input atau dientry oleh fungsi gudang harus melampirkan purchase order (PO) yang telah di tanda tangani dan distampel oleh pihak leasing sebagai bukti bahwa konsumen tersebut sudah mendapatkan persetujuan kredit dari leasing.

2) Surat pesanan kendaraan (SPK) yang akan di input atau dientry oleh fungsi gudang harus mendapatkan otorisasi dari administrasion head $(\mathrm{ADH})$ sebagai bukti persetujuan diskon atau subsidi yang diberikan ke konsumen, dan juga harus ada stampel lunas dari bagian kasir bahwa konsumen sudah membayar uang tanda jadi setelah itu baru surat pesanan kendaraan diberikan kepada fungsi gudang.

3) Fungsi gudang menginput atau mengentry penjualan setelah memastikan dan mengecek bahwa surat pesanan kendaraan yang diterima dari fungsi penjualan dokumennya sudah lengkap dan sudah diotorisasi oleh fungsifungsi yang berwenang.

b. Prosedur pencatatan transaksi penjualan kredit

Berdasarkan hasil penelitian, diketahui PT. Bintang Mulia Jaya sudah melakukan pencatatan transaksi dengan baik dimana semua transaksi penjualan kredit telah dicatat dan dientry sesuai transaksi penjualan kredit.

\section{Praktek yang sehat}

a. Pemeriksaan mendadak

Berdasarkan hasil penelitian, diketahui PT. Bintang Mulia Jaya telah melakukan pemeriksaan mendadak tetapi hanya untuk pemeriksaan persediaan unit atau stok kendaraan.

Seharusnya PT. Bintang mulia jaya juga harus melakukan pemeriksaan mendadak untuk semua fungsi-fungsi yang ada dalam perusahaan yangdilakukan oleh kepala cabang dan administrasion head(ADH) terhadap pekerjaan yang dilakukan oleh masing-masing fungsi yang dilaksanakan tanpa pemberitahuan terlebih dahulu . 
b. Pengambilan cuti

Berdasarkan hasil penelitian, diketahui PT. Bintang Mulia Jaya sudah memberikan hak cuti tahunan kepada semua karyawan tetap yang bisa di ambil bila diperlukan dengan alasan yang jelas, dan pada saat karyawan yang bersangkutan mengambil cuti, jabatannya digantikan sementara oleh karyawan yang lain sehingga seandainya terjadi kecurangan dapat diungkap oleh pejabat yang menggantikan sementara.

c. Pencocokan fisik kekayaan dengan catatan akuntansi

Berdasarkan hasil penelitian, diketahui PT. Bintang Mulia Jaya sudah melakukan pencocokan fisik kekayaan dengan catatan akuntansi yang dilakukan setiap akhir minggu oleh administrasion head, hal ini untuk menjaga kekayaan perusahaan dan mengecek ketelitian dan keandalan catatan akuntansinya.

d. Pembentukan unit organisasi yang bertugas mengecek efektivitas pengendalian intern.

Berdasarkan hasil penelitian. diketahui PT. Bintang Mulia Jaya tidak memiliki unit organisasi yang bertugas mengecek efektivitas pengendalian intern yang dapat memudahkan para pimpinan mengontrol kinerja masingmasing fungsi tanpa harus menunggu pemeriksaan mendadak atau audit intern yang dilakukan oleh kantor pusat.

Seharusnya PT. Bintang mulia jaya membentuk unit organisasi yang bertugas mengecek efektivitas pengendalian intern yang menilai dari lingkungan pengendalian, penaksiran resiko dan aktifitas pengendalian sehingga dapat membuat kebijakan penerapan sistem pengendalian intern penjualan kredit yang dapat digunakan perusahaan dan untuk mengawasi aktivitas yang terjadi diperusahaan.

\section{Sumber daya manusia (SDM) yang kompeten.}

a. Seleksi calon karyawan.

Berdasarkan hasil penelitian, diketahui PT. Bintang Mulia Jaya belum melakukan seleksi calon karyawan secara baik dimana perusahaan memberikan pekerjaan kepada siapa saja tidak melihat latar belakang 
pendidikannya.Akibatnya, karyawan tersebut tidak memahami pekerjaan yang akandikerjakannya. Seharusnya perusahaan memberikan syarat yang lebih khusus untuk seleksi calon karyawannya, seperti untuk calon karyawan bagian gudang harusnya memilih karyawan yang tegas, berkomitmen, bertanggungjawab dandapat berkomunikasi dengan baik pada pihak leasing maupun marketing, dan untuk calon karyawan dibagian keuangan maka seharusnya calon karyawan tersebut memiliki latar belakang pendidikan akuntansi karena lulusan akuntansi telah memiliki dasar mengenai keuangan yang baik dibandingkan dengan lulusan yang lainnya. Perekrutan karyawan yang baik juga hendaknya harus memperhatikan faktor perilaku dalam menentukan kesuksesan dalam bekerja, maka untuk itu perusahaan juga harus memberikan tes psikotest bagi para calon karyawaannya.

Namun, yang terjadi pada PT. Bintang mulia jaya malah sebaliknya.Kepala cabang dan administrasion head (ADH) sebagai penyeleksi karyawan baru tidak melakukan tes psikotest dalam proses perekrutan karyawannya, perusahaan hanya melakukan tes wawancara. Hal ini dikarenakan, perusahaan menganggap dengan melakukan wawancara saja sudah cukup untuk dapat mengetahui latar belakang dan kepribadian dari calon karyawan tersebut.Akibatnya, perusahaan beresiko untuk mempekerjakan karyawan yang memiliki kepribadian yang buruk dan suka melakukan penyimpangan seperti suka mencuri, tidak teliti, tidak disiplin, pemalas, dan tidak patuh terhadap aturan.

b. Pengembangan karyawan

Berdasarkan hasil penelitian, diketahui PT. Bintang Mulia Jaya tidak pernah melakukan pengembangan karyawan dikarenakan perusahaan mengangap sudah cukup memberikan pelatihan kepada karyawan pada saat pertama bekerja (training).

Seharusnya PT. Bintang Mulia Jaya melakukan pelatihan dan pengembangan karyawan secara rutin untuk memberikan sesuatu yang baru dalam pekerjaan, menambah pengalaman kerja bagi karyawan dan dapat menambah wawasan karyawan dalam pengembangan kinerja kerjanya. 


\section{Pengawasan Tambahan}

a. Pelaporan

Berdasarkan hasil penelitian, diketahui PT. Bintang Mulia jaya telah memberikan tanggung jawab dan tugas kepada masing-masing fungsi untuk membuat laporan atas pekerjaan yang sudah dipercayakan kepada masing masing fungsi yang sudah dimasukan ke dalam Job description masingmasing fungsi. Karena pada PT. Bintang Mulia Jaya, laporan merupakan alat yang digunakan untuk memudahkan para pejabat yang berwenang atau atasan baik dikantor pusat dan kantor cabang untuk mengkontrol sejauh mana pekerjaan masing-masing fungsi setiap harinya.

b. AuditIntern

Berdasarkan hasil penelitian, diketahui PT. Bintang Mulia Jaya belum memiliki audit intern.Perusahaan yang tidak memiliki internal audit dikarenakan pimpinan perusahaan mengatakan bahwa perusahaan belum terlalu besar sehingga belum memerlukan auditor internal untuk memeriksa setiap kegiatan operasional perusahaan.Akibatnya, masih ada saja prosedur dan aturan yang tidak dijalankan dengan semestinya dan masih ada beberapa kegiatan yang belum dilakukan dengan maksimal.

Seharusnya PT Bintang Mulia Jaya menyediakan beberapa auditor intern yang sudah terbagi untuk beberapa cabang sehingga dapat melakukan pemeriksaan terhadap pelaksanaan prosedur-prosedur yang telah ditetapkan.Pemeriksaan ini dapat digunakan untuk mengetahui apakah pelaksanaan kerja itu sesuai atau menyimpang dari yang sudah ditetapkan.

\section{Lingkungan Pengendalian}

a. Komitmen atas integritas dan nilai etika

Berdasarkan hasil penelitian, diketahui PT. Bintang Mulia Jaya sudah melakukan pemberian hukuman atau tindakan kepada karyawan yang melakukan kesalahan, tetapi PT. Bintang Mulia Jaya hanya memberikan teguran yang bernilai subjektif. Seharusnya PT. Bintang Mulia Jaya dalam hal ini harus bersikap objektif dalam menilai kesalahan-kesalahan yang dilakukan oleh beberapa fungsi yangberdampak pada kegiatan operasional perusahaan dan berakibat merugikan perusahaan bukan hanya memberikan 
teguran tetapi juga memberikan tindakan yang tegas.surat peringatan (SP) hal ini penting agar pihak yang bersalah benar-benar mendapat hukuman yang sesuai sehingga tidak mengulangi kesalahan itu lagi, jadi apabila karyawan tersebut memang salah, maka karyawan tersebut harus dihukum sesuai dengan tingkat kesalahan yang dilakukannya.

\section{Pembahasan}

Penelitian terdahulu, peneliti melakukan penelitian di perusahaan yang bergerak di bidang mendistribusikan produk bayi merk Johnson's Baby, sedangkan penelitian saat ini penulis melakukan penelitian di bidang sales, service dan sparepart. Di penelitian sebelumnya peneliti terdahulu mengumpulkan data berupa flowchart, serta menganalisa dan mengevaluasi flowchart, sedangkan penelitian saat ini penulis melakukan penelitian dengan carawawancara langsung dengan bagian penagihan piutang, bagian penjualan dan bagian gudang dan mengunakan teknik dokumentasi yakni meminta data yang berhubungan dengan sistem pengendalian intern (SPI) penjualan kredit. Sedangkan di penelitian sebelumnya terdapat juga perbedaan hasil penelitian mengenai untuk memaksimalkan penagihan piutang, misalnya :di penelitian sebelumnya di PT. Supralita Mandiri, belum adanya bagian surveyor untuk calon pelanggan yang akan mengajukan kredit, sehingga kurang mengetahui kondisi calon pelanggan tersebut, sehingga menyebabkan seringnya piuutang tidak tertagih.Sedangkan di penelitian saat ini untuk tim surveyor sudah ada yang dapat langsung survey ke calon konsumen, tetapi yang menjadi permasalahan di PT. Bintang Mulia Jaya bagian penjualan dan penagihan sering lalai melampirkan purchase order dalam penagihan piutang ke bagian leasing.

\section{SIMPULAN DAN SARAN}

\section{Simpulan}

Berdasarkan data yang diperoleh dan analisa yang telah diuraikan pada babIV, baik secara teoritis maupun dilihat dari apa yang terjadi di perusahaan maka penulis mengambil kesimpulan sesuai dengan pokok permasalahan yang ada bahwa: 
1. PT. Bintang Mulia Jaya cabang Palembang belum menerapkan sistem pengendalian intern secara memadai karena di beberapa unsur sistem pengendalian intern penjualan kredit masih banyak yang tidak sesuai dengan teori yang ada dan juga disebabkan tidak dibentuknya unit organisasi untuk menilai atau mengecek efektivitas sistem pengendalian intern penjualan kredit.

2. Petugas atau fungsi-fungsi yang terkait didalam penjualan kredit tidak kompeten salah satunya yaitu bagian gudang yang melakukan transaksi penjualan kredit tanpa meminta otorisasi dari pejabat yang berwenang dan tidak menjalankan standar operasional penjualan kredit sesuai dengan job description yang dibuat oleh perusahaan, disini menunjukan bahwa fungsi gudang melaksanakan tugas dan tanggung jawabnya tidak sesuai dengan standar operasional perusahaan dalam penjualan kredit.

3. Tindakan yang harus diberikan oleh pimpinan perusahaan terhadap permasalahan yang terjadi pada perusahaan, berupa teguran terhadap fungsi yang terkait dalam sistem pengendalian intern penjualan kredit yang mengakibatkan timbulnya permasalahan dalam perusahaan.

\section{Saran}

Berdasarkan kesimpulan yang telah diuraikan sebelumnya, maka sebaiknya perusahaan harus:

1. Melakukan perbaikan penerapan sistem pengendalian intern yang ada pada PT. Bintang Mulia Jaya sesuai dengan teori yang ada pada unsur-unsur sistem pengendalian intern.

2. Lebih memperhatikan setiap transaksi yang berhubungan dengan penjualan kredit apakah sudah terotorisasi semua oleh fungsi yang berwenang sehingga tidak meyebabkan permasalahan dikemudian harinya.

3. Membentuk unit organisasi yang bertugas mengecek efektivitas pengendalian intern penjualan kredit, melakukan pemeriksaan mendadak dan audit intern terhadap kinerja fungsi - fungsi yang ada.

4. Melakukan seleksi ulang karyawan pada fungsi -fungsi yang berhubungan dengan sistem pengendalian intern penjualan kredit dengan membuat kriteria khusus yang sesuai dengan jabatan setelah itu melakukan test tertulis, test 
psikotes dan wawancara, sehingga latar belakang pendidikan dan kemampuan karyawan tersebut cocok dengan jabatan atau posisi yang ditempati.

5. Memberikan teguran berupa surat peringatan (SP) yang keras, serta adil kepada karyawan yang memang melakukan kesalahan serta yang tidak melakukan pekerjaan sesuai dengan standar operasional perusahaandimana kesalahannya berakibat fatal mengakibatkan kerugian pada perusahaan.

\section{DAFTAR PUSTAKA}

A Hall James. 2007. Sistem Informasi Akuntansi. Terjemahan Dewi Fitriasari. Salemba Empat. Jakarta

Almandria putra. 2014. Sistem Pengendalian intern menurut COSO ( online) (http://almandriarp.blogspot.coni/2014/1 l/coso.html,diakses 20 April 2020)

Ardiyos.2007.Kamus Standar Akuntansi.Cetakan Kedua.Jakarta : Citra Harta Prima.

Bambang Supomo, dan Indriantoro, Nur, 2009,Metodologi Penelitian Bisnisuntuk Akuntansi dan Manajemen, Edisi Pertama, BPFE,Yogyakarta.

Baridwan, Zaki. 2002. Sistem Akuntansi(Penyusunan Prosedur dan Metode). Edisi Kelima,cetakan kedelapan. Penerbit BPFE Universitas Gajah Mada.Yogyakarta.

Boynton, William C. Johnson., Raymond N. and Kell, Walter G. “ModernAuditing”,Edisi Ketujuh, Jilid 2, Erlangga, Jakarta. 2001.

Boynton, William C., Raymond N. Johnson., 2006, “Modern Auditing”, 8 th Edition, New York: John Willey \& Sons Inc.

Cahrles T.Horngren dan Walter T.Harrison.2007.Akuntansi Jilid 1, Edisi ke7.Jakarta: Penerbit Erlangga.

Fees, Reeve, Warren, 2005.Pengantar Akuntansi, Edisi 21, Penerbit Salemba Empat, Jakarta.

Littleton, Muhammad, 2002.http://rahasiaakuntansi.blogspot.com /2010/03/ definisi-akuntansi-menurut-para-ahli.html/ diakses tanggal 20 April 2020

Marshall B. Romney dan Paul John Steinbart. 2014. Sistem Informasi Akuntansi: Accounting Information Systems(Edisi 13), Prentice Hall.

Mulyadi. 2001. Sistem Akuntansi. Edisi ketiga Salemba Empat.Yogyakarta. 
Mulyadi. 2001. Sistem AkuntansiEdisi Tiga.Jakarta: Salemba Empat

Mulyadi, 2002. “Auditing”, Buku Dua, Edisi Ke Enam, Salemba Empat.Jakarta.

Mulyadi. 2008. Sistem Akuntansi. Jakarta : Salemba Empat.

Mulyadi. 2013.Sistem Akuntansi,Edisi Ketiga, Cetakan Keempat, Salemba Empat, Jakarta.

Nur dan Bambang.2009. Metode Penelitian. Bandung: Refika Aditama.

Samsuri. 2012. Teori Sistem Pengendalian Intern (online) (https://samsurimunaz.wordpress.com,diakses 20 April 2020).

Skousen, Stice, 2008. Akuntansi Keuangan Menengah. Edisi kesembilan, JilidSatu, Terjemahan. Salemba Empat, Jakarta.

Sugiyono, 2009, Metode Penelitian Kuantitatif, Kualitatif dan R\&D, Bandung : Alfabeta.

Sugiyono. 2009. Metode Penelitian. Bandung: Alfabela.

Sugiyono. 2010. Metode Penelitian Pendidikan Pendekatan Kuantitatif, kualitatif, dan $R \& D$. Bandung: Alfabeta.

Sukrisno, Agoes. 2004. "Auditing (Pemeriksaan Akuntansi)”, Edisi Ketiga, Fakultas Ekonomi Universitas Indonesia. Jakarta.

Stice, Earl K, James D Stice dan Fred Skousen, 2009.Akuntansi Keuangan Menengah, Edisi 16, Buku 2. Edisi Bahasa Indonesia. Terjemah Oleh Ali Akbar. PT. Salemba Empat: Jakarta.

Tita,Rianti. 2014. Prinsip prinsip penilaian kredit ( online) http://blog.stiemce.ac.id/tita/2014/08/3 l/prinsip-prinsip-penilaian-kredit5c-7p-3-r/,diakses 20April 2020).

Tulip, Aras dan Ghozali.Zein. 2019. "Pedoman Penulisan Proposal dan Skripsi" Cetakan Pertama, ISBN: 978-602-53261-5-8, Yogyakarta: Penerbit Aksara Pena.

W Gulo. 2012. Metodelogi Penelitian. Jakarta: Grasindo.

Wilson, James D and John B. Campbell. 2000. Controllership,1998. Terjemahan Tjintjin Fenix Tjendera. Edisi Tiga. Jakarta:Erlangga.

Zaki Baridwan, 2002. Sistem Pengendalian Intern, Edisi Kelima, Penerbit : BPFE, Yogyakarta. 